\title{
THE USE OF ECONOMIC VALUE ADDED AS A BENCHMARK FOR EVALUATING THE PERFORMANCE OF AGRICULTURAL COMPANIES LISTED IN THE IRAQI STOCK EXCHANGE FOR 2010-2015
}

\author{
Salam Neamah Mohammed Ali \\ Agricultural Economy- Department of Industrial Management \\ Collage of Administration \& Economics \\ University of Baghdad- Iraq \\ salamnemaalqara@yahoo.com
}

\begin{abstract}
In order to achieve economic development, investment is one of the biggest economic dimensions with the capability of a playing a major role. As a result, it is considered indispensably urgent in the agricultural sector of Iraq for preparation towards dealing with the rapid change in the world. This will deal with challenges arise from the increase in the amount of imported agricultural goods, increase in local production costs, the need to join the World Trade Organization, open opportunities for investors and increase in market competition. Therefore, the efficiency of the performance of the companies contributing to the Iraqi Stock Exchange is measured by the value added economic criterion (standard) or using benchmark to encourage large number of potential investors who are willing to invest in companies that achieved added value.
\end{abstract}

Keywords: economic value, benchmark, agricultural company, stock exchange

\section{INTRODUCTION}

Regardless of the investor being foreign or native, the strategy of agricultural development has recently provided an opportunity for private companies to invest in the agricultural sector in Iraq (McNellis, 2009). This sector comprises enormous production capacity represented by the abundance of human and not-yet-explored natural resources that has the capacity to increase the accumulation (of economic gains), the added value and necessary capital when invested to achieve a sustainable economic and agricultural development (Cervantes-Godoy, \& Dewbre, 2010).

Many of these projects are in need of investment funding to serve as benefit to the companies contributing to the Iraqi Stock Exchange. Thus, in order to gain development and increase revenue rates, it is important to support those companies which will later on the long- or short-run create a center of attraction for foreign investors to buy shares. Also, supporting those companies is necessary due to constraints of Iraqi investors to enter stock market and to direct the companies on Iraqi investment through scientific evidence (Talab, Abdul Manaf, and Abdul Malak, 2017a, Talab, Abdul Manaf, and Abdul Malak, 2017b, Talab, Abdul Manaf, and Abdul Malak, 2018; Ali, 2015).

With the current situation of Iraq such as decrease in the national income as a result of universal decline in oil prices, increase in the budget earmarked to deal with terrorism and rehabilitating infrastructure, the Iraqi Stock Exchange is obliged to collect and employ local reserves and bring in foreign capitals. Therefore, the availability and dissemination of relevant statistics, database and information including the application of economic value added (EVA) as a benchmark are needed for process of encouraging investments on the agricultural sector and the relevant promotions.

In general, the shareholding companies make one of the most important businesses in private sector of Iraq. The companies collectively function as harmonized economic entity with the aim to achieve many complementary objectives and to attain a certain level of financial performance that reflects the possibility of making judicious use of the available resources. In 2004, the Iraqi Stock Exchange was founded under

Submit Date: 10.01. 2018, Acceptance Date: 23.02.2018, DOI NO: 10.7456/1080MSE/120 
the supervision of Iraqi security commission, an independent body established after the American Securities and Exchange Commission Model. Only six companies make 5.94\% of the total companies registered in the market from the total number of 101 companies listed in the Iraqi Stock Exchange for 2007. According to the semi-annual report for 2017 and the directory of joint stock companies of Iraq Stock Market, the market value of listed companies for the year 2016 was 10.457 trillion dinars with the share of agricultural companies reaching $0.067 \%$ and the ratio of these shares to the total value of shares traded was $0.81 \%$ for the year 2016 (Al-Aqidi, 2012; ISX reports; Central Bank of Iraq Statistical).

Table 1: The List of Companies Specializing in the Agricultural Sector in the Iraqi Stock Exchange

\begin{tabular}{|c|c|c|c|c|c|c|}
\hline & Name & $\begin{array}{l}\text { Type of the } \\
\text { company }\end{array}$ & Activity & $\begin{array}{l}\text { D a t e of } \\
\text { establishment }\end{array}$ & $\begin{array}{l}\text { D a t e } \quad \text { o f } \\
\text { c a p i t a } 1 \\
\text { enrolment }\end{array}$ & $\begin{array}{l}\text { Amount of the } \\
\text { capital (IQD) }\end{array}$ \\
\hline 1 & $\begin{array}{l}\text { The Modern } \\
\text { Company for } \\
\text { Animal and } \\
\text { Agricultural } \\
\text { Production }\end{array}$ & $\begin{array}{l}\text { Joint-Stock } \\
\text { Company }\end{array}$ & $\begin{array}{l}\text { Production } \\
\text { o f } \\
\text { agricultural } \\
\text { and animal } \\
\text { crops }\end{array}$ & 25/3/1991 & 25/3/1991 & $4,101,300,000$ \\
\hline 2 & $\begin{array}{l}\mathrm{P} \mathrm{r} \mathrm{i} \text { a } \mathrm{te} \\
\text { Company for } \\
\mathrm{A} \mathrm{n} \mathrm{i} \mathrm{m} \text { a } 1 \\
\text { Production }\end{array}$ & $\begin{array}{l}\text { Joint-Stock } \\
\text { Company }\end{array}$ & $\begin{array}{l}\mathrm{F} \quad \mathrm{i} \quad \mathrm{s} \text { h } \\
\text { breeding and } \\
\text { marketing } \\
\text { a } \mathrm{n} \text { d } \\
\text { production of } \\
\text { f i h a } \mathrm{h} d \\
\text { poultry feed } \\
\text { for the } \\
\text { company and } \\
\text { others }\end{array}$ & 6/9/1994 & $30 / 6 / 2017$ & $575,000,000$ \\
\hline 3 & $\begin{array}{l}\text { Middle East } \\
\text { F i s } \mathrm{h} \\
\text { Production \& } \\
\text { Marketing } \\
\text { Company }\end{array}$ & $\begin{array}{l}\text { A Joint-Stock } \\
\text { Company }\end{array}$ & $\begin{array}{l}\text { Breeding and } \\
\text { marketing of } \\
\text { f is h a n d } \\
\text { exploitation } \\
\text { of non-arable } \\
\text { l a nd s a s } \\
\text { bodies of } \\
\text { water (fish } \\
\text { ponds) }\end{array}$ & 9/8/1994 & $30 / 6 / 2017$ & $300,000,000$ \\
\hline 4 & $\begin{array}{l}\text { Iraqi Seed } \\
\text { Production } \\
\text { Company }\end{array}$ & $\begin{array}{l}\text { A } \mathrm{Mix} \text { e d } \\
\text { Corporation }\end{array}$ & $\begin{array}{l}\text { Production } \\
\text { a n d } \\
\text { marketing of } \\
\text { chicken, fish, } \\
\text { eggs of all } \\
\text { kinds and } \\
\text { small animal } \\
\text { islands }\end{array}$ & $10 / 5 / 1989$ & $30 / 6 / 2017$ & $7,500,000,000$ \\
\hline
\end{tabular}

Submit Date: 10.01. 2018, Acceptance Date: 23.02.2018, DOI NO: 10.7456/1080MSE/120 


\begin{tabular}{|c|c|c|c|c|c|c|}
\hline & Name & $\begin{array}{l}\text { Type of the } \\
\text { company }\end{array}$ & Activity & $\begin{array}{l}\text { D a t e of } \\
\text { establishment }\end{array}$ & $\begin{array}{l}\text { D a t e } \quad \text { o f } \\
\text { c a p i t a } 1 \\
\text { enrolment }\end{array}$ & $\begin{array}{l}\text { Amount of the } \\
\text { capital (IQD) }\end{array}$ \\
\hline 5 & $\begin{array}{l}\mathrm{I} \text { r a } \mathrm{q} \\
\text { Company for } \\
\mathrm{t} \mathrm{h} \text { e } \\
\text { Production } \\
\mathrm{a} \mathrm{n} \text { d } \\
\text { Marketing of } \\
\text { Me a } \mathrm{t} \text { a } \mathrm{d} \\
\text { Field Crops }\end{array}$ & $\begin{array}{l}\text { M i x e d } \\
\text { corporation }\end{array}$ & $\begin{array}{l}\text { Production } \\
\text { a } \mathrm{n} d \\
\text { marketing of } \\
\text { chicken, fish } \\
\text { a } \mathrm{d} \text { e g } \\
\text { production of } \\
\text { all kinds }\end{array}$ & 13/6/1987 & $30 / 6 / 20117$ & $5,000,000,000$ \\
\hline 6 & $\begin{array}{l}\mathrm{I} \text { r a } \mathrm{q} \text { i } \\
\text { Company for } \\
\mathrm{t} \mathrm{h} \text { e } \\
\text { Production } \\
\mathrm{a} \mathrm{n} \text { d } \\
\text { Marketing of } \\
\text { Agricultural } \\
\text { Products }\end{array}$ & $\begin{array}{l}\text { A M i x e d } \\
\text { Corporation }\end{array}$ & $\begin{array}{l}\text { Production } \\
\text { a } \mathrm{n} \quad \mathrm{d} \\
\text { marketing of } \\
\text { agricultural } \\
\text { products }\end{array}$ & NA & $30 / 6 / 2017$ & $360,000,000$ \\
\hline
\end{tabular}

According to the Directory of Joint Stock Companies, Iraq Stock Exchange 2017, the total number of agricultural companies listed in the Iraqi Stock Exchange till 31/6/2017 was 6 with a total capital of 22,476,300,000 IQD.

There has been a challenge in the possibility of integrating the two concepts of accounting income and economic value added as criteria for presenting and measuring the performance of companies' involvement in the Iraqi Stock Exchange. This study shows the way economic value added is more adaptable to be used in evaluating performance in comparison to other measurement. Therefore, the aim of this study is to unveil the importance of the economic value added for shareholders and to implement the EVA pertinent to the agricultural companies contributing to the Iraqi Stock Exchange and to display EVA as one of the effective devices to regulate the economic activities of the companies (Said \& Samir, 2014).

The first section of the study is the introduction while the second section presents a theoretical approach aimed at evaluating the performance and development of the concept of economic value added its importance and its relationship to share prices and shareholders. The third section comprises the financial analysis of the economic value added pertinent to the agricultural companies involved in the Iraqi Stock Exchange over the period 2010-2015. The last section highlights the conclusions and recommendations.

\section{LITERATURE REVIEW}

The Evaluation of Economic Performance and the Development of the Concept of Economic Value Added and its Importance and Relationship to Stock Prices and Stakeholders

For any stock joint company looking forward to attract more investor, its main goal should be the maximization of profits. Optimization of the profit will maximize the value of its share in the market (Talab, 2009; Shleifer, 2000). To achieve better returns, the company is continuous need of a constant evaluation of its shares/stocks in the financial markets. By providing financial information about the performance to the employees, shareholders and investors in the company, the evaluation of the performance plays a big role in how the company is to be managed (Mashhadani and Talab, 2013). This will help in the process of economic decision-making and thus enhances the evaluation of the company's performance using the increase or decrease indicator in the share values with the profit distribution as achieved by the company. The information and data needed to be used in measuring the extent at which a

Submit Date: 10.01. 2018, Acceptance Date: 23.02.2018, DOI NO: 10.7456/1080MSE/120 
company achieves its planned objectives and identifies its direction are provided by the board of the company in the performance evaluation process.

The shareholding companies seeking to achieve and maximize profits recognize the importance of financial statements due to their need for information pertinent to raising the value of the given share and its return (Stiglitz, 1993). This is in addition to securing survival in a market known for competition and to attract prospective shareholders and investors. The evaluation of the shares and its returns both now and in the future is subject to the current economic situations and to the expected expansion of markets since using methods of evaluating the financial performance of a company has proved to be more effective than those used to evaluate its accountings (Koller, Goedhart, \& Wessels, 2010). Therefore, reliance on the performance evaluation is more beneficial in showing the impact on the national income and the economy as a whole. This attempts to shift the financial function from accounting activity to economic activity.

The idea began economically from Alfred Marshall when he first suggested the idea of economic income in terms of a real profit in 1890. As the importance of this topic increased over the years, in 1993, fortune magazine described the economic value added as the most promising financial idea. The EVA is one of modern benchmarks that focuses and relies on the value-based evaluation of earing per share (EPS); it is an advanced concept of residual profit. EVA is directly and closely connected with the value-creating process. It has succeeded in creating a precise definition of real profit and measuring the ability of the company to create value for shareholders unlike other traditional measures (Awan, Siddique, \& Sarwar, 2014; Stern, Shiely, \& Ross, 2001; Al-Shibli, 2009).

A lot of attention has been paid to the importance of the shareholders and their activities in the last century in order to find a place for the stakeholders to achieve stability and reasonable returns under the market conditions. This is in addition to provision of transparent information which enables investors and shareholders to make a great contribution to the process of reducing the differences between the shareholders and company management/board. It would result to value creation for shareholders in terms of abundant wealth increaseonce this harmony is created in the long run. Investments in those companies eventually look more appealing through the capacity created (Flayyih, 2015a).

Alfred Rapport was among the pioneers in this subject who wrote a book "Creating Shareholder Value" in 1986 then followed by other scholars who tried to connect economics as science to the accounting practices as a profession. Economic Value Added (EVA) became one of the most common benchmarks in present time due to the significance of the connection and was first implemented by Citron Stewart \& Co. in 1990 (Maditinos, Šević, \& Theriou, 2007). What makes EVA unique is the fact that it differs from profit but only concerned about the factors affecting and to determine shares' value in accordance with the wealth of the shareholders. The profits is expected to be obtained from a given project over its lifetime along with the risks and uncertainties associated with achieving these profits through the changes that occur from the volume of future flows of cash (Zafiris, \& Bayldon, 1999).

In another vein, EVA is defined as a measure of financial performance used in estimating real profit as it is effective in maximizing shareholder's wealth over the time (Stern \& Stewart, 1995; Flayyih, 2015b). Hamza, (2014) also defined EVA as the difference between net operating profit (after deducting taxes) and the cost of the owned and borrowed capital. Similarly, it is defined as the benchmark for measuring performance through identification of methods that contribute to raising and eliminating the companies' values. This is obtainable since after considering alternative opportunities for shareholders, EVA allows determination of profits that are remained after subtracting capital costs (Saifi, and Amara, 2015).

\section{The Importance of EVA as a Benchmark}

The following are the importance of EVA when used as a benchmark:

The company's real economic profit is focused on by concentrating on the cost of both borrowed and owned capital without relying on the sales figures.

Submit Date: 10.01. 2018, Acceptance Date: 23.02.2018, DOI NO: 10.7456/1080MSE/120 
Direction of manager's ideas on whether a given investment would raise more profits compared to the cost of the capital invested or not.

A company can easily achieve annual profits the capital gains through the increase in stock values in the market. Thus, EVA allows shareholders to predict the future returns of the shares in the stock market.

It has the capacity to bring about change at all levels of management and in the behavior of a company through the harmony achieved from the objectives of managers, investors and shareholders.

The importance of EVA becomes evident more in the case of decisions taken to launching new investment(s) and to expand the investment activity of the company.

Optimization of the primary goal of the company being the wealth of the shareholders.

\section{Calculation of EVA}

By considering EVA as the difference between the Net Operating Profit after Taxes (NoPAT) and the capital charge (invested), Sterm Stewart Company was able to determine the economic value added using the following formulae (Harad, 2014):

Economic Value added $=$ Net Operating Profit after Taxes - Weighted Average Cost of Capital (WACC) X Capital Invested

$\mathrm{EVA}=$ NOPAT $-($ WACC $\times$ Capital invested $)$

The above formulae shall be used to calculate EVA in this study; it is simplified as:

$\mathrm{EVA}=(\mathrm{SA}-\mathrm{VE}-\mathrm{FE}-\mathrm{DA})-\mathrm{CC}-\mathrm{T}$

Where SA represents sales revenue, VE for fixed costs, FE for variable costs, DA for administrative costs, $\mathrm{CC}$ for average weighted cost of capital, and T for taxes (Mohammed, 2013).

From the economic perspective, the company would create economic value added when the return on the company's capital is greater than the cost of the alternative opportunity. Through the influence on the market prices of stocks, a positive EVA would result in having positive impact on the shareholders' wealth and vice versa (Ray, 2012).

The following are the conditions required for calculating EVA:

The company's disclosure of descriptive and quantitative financial information to external shareholders and investors and to those who have no authority over relevant books and records will lead to greater transparency.

The implementation of the benchmark requires that certain accounting adjustments are employed on the relation to research and development; also on expenses related to advertisement and extraordinary losses and profits.

\section{RESEARCH METHODOLOGY}

This study employed descriptive method to study the importance and calculation of EVA. Also, the predictive method was applied to deal with its application on the agricultural companies that contribute to the Iraqi Stock Exchange. A sample of six shareholding agricultural companies contributing to the Iraqi stock exchange was selected. In order to achieve the research aim, all agricultural shareholding companies registered at the Iraqi Stock Exchange were selected and considered as representatives of the community. Relevant data were collected from the official statements issued by the Iraqi Stock Exchange of the Central Bank of Iraq and the details of the accounts issued by the companies involved within the period of 2010 to 2015.

\section{RESULTS AND DISCUSSION}

\section{The Economic Value Added (EVA)}

A complex calculation is required for determining EVA due to the compound cost involved since EVA represents differences between the net profit after deducting tax and the cost of the invested capital. This involves calculating the costs of debt financing and the cost of equity financing; then calculating the weighted average cost of capital. These compound costs would be discussed within this section as the base for calculating the economic value added in terms of the aforementioned compound costs and finally determining the EVA of the companies considered in the research sampling.

Submit Date: 10.01. 2018, Acceptance Date: 23.02.2018, DOI NO: 10.7456/1080MSE/120 
The Cost of Debt Financing: the following equation is used to calculate the cost of debt finance Cost of Debt $=K D^{*}(1-\mathrm{T})$

Where KD isInterest on debt, $\mathrm{T}$ is the percentage of tax (T-1) saving.

Most companies resort to debts to finance their investments in order to achieve tax savings since the cost would decrease as the relevant tax rate decreases because the associated interest is considered a fixed taxexempt income and thus the increase in the tax rate would contribute to achieving higher rates of tax savings for companies. The interest rates were selected based on the rates approved by the Iraqi Central Bank during the period of 2010-2015. Likewise, the percentage of the taxation was determined according to the tax imposed on each company that appears in the company's financial statements.

Table (2)

Rates of Debt-Financing Costs KD*(1-T) for Researched Sampling Companies over the Period (2010-2015)

\begin{tabular}{|l|l|l|l|l|l|l|l|l|}
\hline Ref. & Company & 2010 & 2011 & 2012 & 2013 & 2014 & 2015 & \multicolumn{2}{|l|}{ Rate } \\
\hline 1 & $\begin{array}{l}\text { The Modern Company for } \\
\text { Animal and Agricultural } \\
\text { Production }\end{array}$ & 0.143 & 0.140 & 0.139 & 0.136 & 0.126 & 0.123 & 0.135 \\
\hline 2 & $\begin{array}{l}\text { Private Company for } \\
\text { Animal Production }\end{array}$ & 0.143 & 0.140 & 0.126 & 0.136 & 0.126 & 0.123 & 0.132 \\
\hline 3 & $\begin{array}{l}\text { M id d l e E a s t F i s h } \\
\text { Production \& Marketing } \\
\text { Company }\end{array}$ & 0.126 & 0.117 & 0.122 & 0.116 & 0.103 & 0.100 & 0.114 \\
\hline 4 & $\begin{array}{l}\text { Iraqi Seed Production } \\
\text { Company }\end{array}$ & 0.143 & 0.140 & 0.138 & 0.135 & 0.126 & 0.123 & 0.134 \\
\hline 5 & $\begin{array}{l}\text { Iraqi Company for the } \\
\text { Production and Marketing } \\
\text { of Meat and Field Crops }\end{array}$ & 0.143 & 0.121 & 0.117 & 0.111 & 0.103 & 0.101 & 0.116 \\
\hline 6 & $\begin{array}{l}\text { Iraqi Company for the } \\
\text { Production and Marketing } \\
\text { of Agricultural Products }\end{array}$ & 0.128 & 0.119 & 0.123 & 0.118 & 0.126 & 0.123 & 0.123 \\
\hline
\end{tabular}

The table was done by the researcher depending on the equation above.

The rates of debt-financing costs recorded by the researched sampling companies over the period of 2010 to 2015 are presented in the results of the table above. In terms of those rates from the Middle East for the Production and Marketing of Fish Company registering the lowest rate (0.100), the result shows that the companies get closer to each other. The result for the Iraqi Company for the Production and that of the Marketing of Meat and Field Crops company for the same year was 0.101 . The highest result of 0.143 was found in the majority of companies for the year 2010 except in the Middle East for the Production and Marketing of Fish Company. A lower cost was recorded in the Iraqi Company for the Production and Marketing of Agricultural Products.

\section{The Cost of Equity Financing}

This is the representation of the minimum limit for the required rate of return required for the investors for the compensation of the risks likely to be suffered by the investment within the stocks of the company. This is equivalent to the opportunity cost faced by the investors due to their investments. The rate is positively related to the risks; the more risks are taken, the more the value of the equity costsbecomes as a direct result to the additional returns sought by the investors in order to compensate them for the risks they accept. The equity cost is determined using the same formula used to calculate the Capital Asset

Submit Date: 10.01. 2018, Acceptance Date: 23.02.2018, DOI NO: 10.7456/1080MSE/120 
Pricing Model (CAPM). The formula is considered as the commonest method used in this field and it is mathematically expressed as follows:

$\mathrm{KE}=\mathrm{RF}+(\mathrm{RM}-\mathrm{RF}) * \beta$

Where: Where RF is the risk-free rate of return; the RM is the average expected rate of return on the market, and the coefficient $\beta$ representing the relative (regular) market risk.

Table (3)

Risk-free rate of return for the period (2010-2015)

\begin{tabular}{|l|l|}
\hline Years & RF \\
\hline 2010 & 0.072 \\
\hline 2011 & 0.069 \\
\hline 2012 & 0.070 \\
\hline 2013 & 0.066 \\
\hline 2014 & 0.051 \\
\hline 2015 & 0.053 \\
\hline
\end{tabular}

Source: Statistical publications issued by the Central Bank of Iraq/Directorate General of Statistics and Research

On the other hand, the annual returns of the market portfolio represent the change in prices between one year and another. Table 4 below shows the annual market prices attained relying on the total monthly prices achieved by all companies registered in the Iraqi Stock Exchange.

Table (4)

Average Market Return (RM) for the period (2010-2015)

\begin{tabular}{|l|l|}
\hline Years & Average Market Return \% \\
\hline 2010 & 0.120 \\
\hline 2011 & 0.347 \\
\hline 2012 & 0.081 \\
\hline 2013 & 0.095 \\
\hline 2014 & 0.187 \\
\hline 2015 & 0.268 \\
\hline
\end{tabular}

Resource: Annual reports issued by the Iraqi Stock Exchange Market

Due to fluctuations occurring in returns of the market portfolio, the determination of beta values requires measuring the sensitivity of stock returns. Through the application of the formula below, the value of the beta coefficient can be calculated mathematically as:

$$
\beta=\frac{\operatorname{COV}(\mathrm{yx})}{\operatorname{VAR} \mathrm{x}}
$$

The VAR $\mathrm{x}$ represents the variance of market portfolio while the COV (yx) is the common variance between stock returns and market returns.

The market and stock returns are derived depending on the monthly stock prices and market price of each company. The difference between the current share price and the previous share price divided by the previous share priceis represented by earning per share. The same method used in working out earning is

Submit Date: 10.01. 2018, Acceptance Date: 23.02.2018, DOI NO: 10.7456/1080MSE/120 
applied to market portfolio returns. The table 5 below presents the Monthly monitoring of the stock prices and the market prices that are used other than beta coefficient.

Table (5)

$\beta$ Beta Coefficient for the researched sampling companies for the period (2010-2015)

\begin{tabular}{|c|c|c|c|c|c|c|c|}
\hline Ref. & Company & 2010 & 2011 & 2012 & 2013 & 2014 & 2015 \\
\hline 1 & $\begin{array}{l}\text { The Moder } \mathrm{e} \\
\text { Company for Animal } \\
\text { and Agricultural } \\
\text { Production }\end{array}$ & 0.583536 & $0.03467-$ & -0.008868 & 0.0014686 & -0.46618 & 0.062289 \\
\hline 2 & $\begin{array}{l}\text { Private Company for } \\
\text { Animal Production }\end{array}$ & 0.911728 & 0.339492 & 0.002510 & 0.614352 & -0.706131 & 0.282337 \\
\hline 3 & $\begin{array}{l}\text { Middle East Fish } \\
\text { Production \& } \\
\text { Marketing Company }\end{array}$ & 2.385979 & 0.692404 & 0.732592 & 3.472231 & 0.229941 & 0.05548 \\
\hline 4 & $\begin{array}{lr}\text { I r a q i } & \text { S e e d } \\
\text { Production Company }\end{array}$ & 0.062289 & -0.706131 & -0.042596 & 0.339492 & 0.410811 & 0.583536 \\
\hline 5 & $\begin{array}{l}\text { Iraqi Company for } \\
\text { the Production and } \\
\text { Marketing of Meat } \\
\text { and Field Crops }\end{array}$ & 0.282337 & 0.732592 & 0.012265 & -0.000681 & -1.50094 & 0.911728 \\
\hline 6 & $\begin{array}{l}\text { Iraqi Company for } \\
\text { the Production and } \\
\mathrm{M} \text { a r k e t i n g o f } \\
\text { A g r i c u } 1 \mathrm{t} \mathrm{u} \mathrm{r} \mathrm{a} 1 \\
\text { Products }\end{array}$ & 0.614352 & 0.462385 & $0.03467-$ & 0.307055 & $0.20607-$ & 0.288034 \\
\hline
\end{tabular}

\section{Resource: The table was made by the researcher.}

Possible explanations of beta coefficient values can be illustrated as follows:

$0>\beta$ Reverse correlation between stock returns and market returns

$0=\beta$ There is no correlation between stock returns and market returns

$1>\beta>0$ Positive correlation and the change in stock returns is less than the change in market returns

$1=\beta$ The correlation is positive as stock returns change with the same rate of the change occurring in market returns

$1<\beta$ Positive correlation and change in stock returns is greater than the change in market returns

Submit Date: 10.01. 2018, Acceptance Date: 23.02.2018, DOI NO: 10.7456/1080MSE/120 
The rate of cost of equity financing is then calculated after all the CAPM variables have been completed including its three aforementioned elements. Table 6 shows costs of equity financing of the selected companies over the period 2010 to 2015.

Table (6)

Rates of Costs of Equity Financing (KE)for the Researched Companies over the Years (2010-2015)

\begin{tabular}{|c|c|c|c|c|c|c|c|c|}
\hline Ref. & Company & 2010 & 2011 & 2012 & 2013 & 2014 & 2015 & Rate \\
\hline 1 & $\begin{array}{l}\text { The Modern Company } \\
\text { for A n i m a l a n d } \\
\text { Agricultural Production }\end{array}$ & 0.100 & 0.059 & 0.071 & 0.066 & 0.162 & 0.033 & 0.082 \\
\hline 2 & $\begin{array}{l}\text { Private Company for } \\
\text { Animal Production }\end{array}$ & 0.116 & 0.163 & 0.070 & $0.033-$ & $0.095-$ & 0.038 & 0.043 \\
\hline 3 & $\begin{array}{l}\text { Middle East Fish } \\
\text { Production \& } \\
\text { Marketing Company }\end{array}$ & 0.182 & 0.261 & $0.040-$ & $0.493-$ & $3.726-$ & 0.035 & $0.630-$ \\
\hline 4 & $\begin{array}{l}\text { Iraqi Seed Production } \\
\text { Company }\end{array}$ & 0.078 & $0.127-$ & 0.076 & 0.011 & $0.047-$ & $0.134-$ & $0.024-$ \\
\hline 5 & $\begin{array}{l}\text { Iraqi Company for the } \\
\text { P r o d u c t i o n a n d } \\
\text { Marketing of Meat and } \\
\text { Field Crops }\end{array}$ & 0.088 & 0.273 & 0.068 & 0.066 & 0.408 & $0.240-$ & 0.111 \\
\hline 6 & $\begin{array}{l}\text { Iraqi Company for the } \\
\text { Production and } \\
\text { M arketing of } \\
\text { Agricultural Products }\end{array}$ & 0.103 & 0.198 & 0.075 & 0.017 & 0.100 & $0.039-$ & 0.076 \\
\hline
\end{tabular}

\section{Resource: The table was made by the researcher.}

The table 6 above shows the cost of equity financing for the sampling companies over the researched period 2010 to 2015. From these results, it is noted that the rates of interest on debts is lower than the rate of the rates of costs of equity financing as shown in table 1. This implies that financing companies through the equity financing method affects those companies more than the interests pai on debts. This can be traced to many reasons such as tax-saving benefit and debt finance since the cost of debts represented in intersts are tax-exempted; which means it decreases the overal profits calculated before deducting taxes contrary to what happens if equity financing method is adopted where costs of equity are deducted from the net profits after deducting the taxes. This has nothing to do with the high costs related to the process of stock trading as connected with issuing bonds.

Similarly, the equity cost is related to the volatility risks of the shares related to the company measure by beta coefficient for whenever the value of this coefficient is raised, the cost of quity is similarily raised. Some of the results show this correlation as compared to the selected companies since there is a high rise in the rate of equity cost. Thus, this led to a rise in the beta coefficient of those companies as an indication to the big risks the companies were facing.

The decrease or increase in the rates of the cost of equity of the companies is connected with the rate of risks each company is exposed to in terms of volatility of stock returns due to the fluctuations in market returns expressed by a beta coefficient for the systematic (regular) risk of the selected companies.

Submit Date: 10.01. 2018, Acceptance Date: 23.02.2018, DOI NO: 10.7456/1080MSE/120 
Therefore, the company is likely to face less risk whenever the beta coefficient value is small (less than positive 1). This is as a result of reduction in sensitivity of the stock return in relation to the changes taking place in the market returns especially in case of a big drop in market returns. In addition, the company is likely to face big risks, whenever the beta coefficient value is bigger than (1). This can be ascribed to the fact that changes in market returns will result to bigger changes in the company's stock returns. When the beta coefficient value is zero, the company faces no risks since any negative change in the market returne will have no impact on the stock returns of the company which was shown as an example of the Middle East Fish Production and Marketing Company in table 6. From the example, there is low rate of equity cost of -3.726 for a year which coincides with a beta coefficient value of zero in the year 2014. The highest rate of equity financing cost of 0.273 was recorded in the case of Iraqi Company for the Production and Marketing of Meat and Field Crops for the year 2011.

Ratios of Debt Financing (D / E + D) and Ratios of Equity Financing (E / E + D)

Table (7)

Ratios of Debt Financing (D / E + D) and Ratios of Equity Financing (E / E + D).

\begin{tabular}{|c|c|c|c|c|c|c|c|c|}
\hline Ref. & Company & $\begin{array}{l}\text { F in a n c ing } \\
\text { Ratio }\end{array}$ & 2010 & 2011 & 2012 & 2013 & 2014 & 2015 \\
\hline \multirow[b]{2}{*}{1} & \multirow{2}{*}{$\begin{array}{l}\text { The Modern } \\
\text { Company for } \\
\text { Animal and } \\
\text { Agricultural } \\
\text { Production }\end{array}$} & Debt Ratio & 33.03 & 45.04 & 47.22 & 25.84 & 23.11 & 21.99 \\
\hline & & Equity Ratio & 66.97 & 54.96 & 52.78 & 74.16 & 76.89 & 78.01 \\
\hline \multirow[b]{2}{*}{2} & \multirow{2}{*}{$\begin{array}{l}\mathrm{P} \mathrm{r} \mathrm{i} \text { a } \mathrm{t} \text { e } \\
\text { Company for } \\
\mathrm{A} \mathrm{n} \mathrm{i} \mathrm{m} \text { a } 1 \\
\text { Production }\end{array}$} & Debt Ratio & 17.93 & 14.81 & 28.85 & 14.98 & 13.69 & 12.62 \\
\hline & & Equity Ratio & 82.07 & 85.19 & 71.15 & 85.02 & 86.31 & 87.38 \\
\hline \multirow[b]{2}{*}{3} & \multirow{2}{*}{$\begin{array}{l}\text { Middle East } \\
\text { F i s h } \\
\text { Production \& } \\
\text { Marke ti } \mathrm{g} \\
\text { Company }\end{array}$} & Debt Ratio & 36.43 & 19.82 & 23.24 & 24.86 & 22.39 & 16.61 \\
\hline & & Equity Ratio & 63.57 & 80.18 & 76.76 & 75.14 & 77.61 & 83.39 \\
\hline \multirow{2}{*}{4} & \multirow{2}{*}{$\begin{array}{l}\text { Iraqi Seed } \\
\text { Production } \\
\text { Company }\end{array}$} & Debt Ratio & 86.89 & 76.92 & 69.61 & 74.22 & 85.86 & - \\
\hline & & Equity Ratio & 13.11 & 23.08 & 30.39 & 25.78 & 14.14 & - \\
\hline \multirow[b]{2}{*}{5} & \multirow{2}{*}{$\begin{array}{l}\text { Iraqi Company } \\
\text { f o } \mathrm{r} \text { th e } \\
\text { Production and } \\
\text { Marketing of } \\
\text { Meat and Field } \\
\text { Crops }\end{array}$} & Debt Ratio & 30.62 & 34.92 & 33.07 & 28.24 & 29.24 & 27.58 \\
\hline & & Equity Ratio & 69.38 & 65.08 & 66.93 & 71.76 & 70.75 & 72.42 \\
\hline \multirow[b]{2}{*}{6} & \multirow{2}{*}{$\begin{array}{l}\text { Iraqi Company } \\
\text { for th e } \\
\text { Production and } \\
\text { Marketing of } \\
\text { Agricultural } \\
\text { Products }\end{array}$} & Debt Ratio & 9.18 & 11.87 & 12.81 & 16.1 & 9.76 & 12.47 \\
\hline & & Equity Ratio & 90.82 & 88.13 & 87.81 & 83.90 & 90.24 & 87.53 \\
\hline
\end{tabular}

The Weighted Average Cost of Capital (WACC)

Submit Date: 10.01. 2018, Acceptance Date: 23.02.2018, DOI NO: 10.7456/1080MSE/120 
It is possible to calculate the weighted average cost of capital after determining both the cost of debt financing and the cost of equity financing which is equal to the sum of the cost of debt and the cost of equity multiplied by the debt and equity ratios used by the company in its capital structure as presented in the below formula:

$$
\mathrm{WACC}=\frac{\mathrm{E}}{\mathrm{E}+\mathrm{D}} * \mathrm{KE}+\frac{\mathrm{D}}{\mathrm{E}+\mathrm{D}} * \mathrm{KD}(1-\mathrm{T})
$$

Where: $\mathrm{E} /(\mathrm{E}+\mathrm{D})$ is the ratio of equity to total capital invested; $\mathrm{D} /(\mathrm{E}+\mathrm{D})$ is the ratio of debt to capital; $\mathrm{KE}$ is the cost of equity rate; $\mathrm{KD}$ is the cost of debt; and1-T is the tax savings.

Table (8)

Results of Weighted Average Cost of Capital (WACC) for the researched companies

\begin{tabular}{|c|c|c|c|c|c|c|c|c|}
\hline Ref. & Company & 2010 & 2011 & 2012 & 2013 & 2014 & 2015 & Average \\
\hline 1 & $\begin{array}{l}\text { The Modern Company } \\
\text { for A n i m a l a n d } \\
\text { Agricultural Production }\end{array}$ & 11.420 & 9.677 & 10.311 & 8.409 & 15.368 & 5.279 & 10.077 \\
\hline 2 & $\begin{array}{l}\text { Private Company for } \\
\text { Animal Production }\end{array}$ & 12.084 & 28.836 & 8.539 & 12.174 & -6.189 & 5.669 & 10.186 \\
\hline 3 & $\begin{array}{l}\text { Middle East Fish } \\
\text { Production \& } \\
\text { Marketing Company }\end{array}$ & 16.160 & 23.166 & -0.653 & -34.160 & -29.614 & 4.955 & -8.293 \\
\hline 4 & $\begin{array}{l}\text { Iraqi Seed Production } \\
\text { Company }\end{array}$ & 13.448 & 7.838 & 11.916 & 10.303 & 10.154 & 0 & 8.943 \\
\hline 5 & $\begin{array}{l}\text { Iraqi Company for the } \\
\text { P r o d u c } \mathrm{i} \text { o } \mathrm{n} \text { a } \mathrm{n} \\
\text { Marketing of Meat and } \\
\text { Field Crops }\end{array}$ & 10.484 & 21.992 & 9.087 & 7.871 & 31.878 & 10.824 & 15.356 \\
\hline 6 & $\begin{array}{l}\text { Iraqi Company for the } \\
\text { Production an d } \\
\text { M arketing of } \\
\text { Agricultural Products }\end{array}$ & 10.530 & 18.862 & 8.161 & 3.326 & 10.254 & -1.880 & 50.253 \\
\hline
\end{tabular}

It is possible to determine the economic value of the selected companies for the period of 2010 to 2015after obtaining the necessary financial data from the financial statements of the sample companies (such as the net profit after deducting taxes and the total capital invested) and after determining the components of the compound costs included in the economic value added equation using the formula below:

$\mathrm{EVE}=$ NOPAT $-(\mathrm{WACC} * \mathrm{IC})$

Where: NOPAT is the net profit after deducting the taxes; IC is the invested capital; and WACC is the weighted average cost of capital.

The economic value added achieved for each of the six selected companies over the period of 2010 to 2015 is illustrated in the table 9 below:

Table (9)

\section{Results of Economic Value Added for the Researched Sampling over the Period (2010-2015)}

Submit Date: 10.01. 2018, Acceptance Date: 23.02.2018, DOI NO: 10.7456/1080MSE/120 


\begin{tabular}{|c|c|c|c|c|c|c|c|c|}
\hline Ref & Company & 2010 & 2011 & 2012 & 2013 & 2014 & 2015 & Average \\
\hline 1 & $\begin{array}{l}\text { The Modern } \\
\text { Company for } \\
\text { Animal and } \\
\text { Agricultural } \\
\text { Production }\end{array}$ & -3400461 & -4067196 & $\begin{array}{l}-46674 \\
83\end{array}$ & $\begin{array}{l}-54667 \\
79\end{array}$ & -1.013631 & $\begin{array}{l}-35392 \\
62\end{array}$ & $\begin{array}{l}-521292 \\
1\end{array}$ \\
\hline 2 & $\begin{array}{l}\text { Private Company } \\
\text { for A n i m a } 1 \\
\text { Production }\end{array}$ & 0 & -5695073 & $\begin{array}{l}-17529 \\
93\end{array}$ & 0 & 0 & 0 & $\begin{array}{l}-124134 \\
4\end{array}$ \\
\hline 3 & $\begin{array}{l}\text { Middle East Fish } \\
\text { Production \& } \\
\text { M a r k e t i n g } \\
\text { Company }\end{array}$ & -8226525 & -3250067 & $\begin{array}{l}110706 \\
0\end{array}$ & $\begin{array}{l}508941 \\
4\end{array}$ & 4668054 & $\begin{array}{l}-83207 \\
08\end{array}$ & 8272305 \\
\hline 4 & $\begin{array}{l}\text { Ir a q i S e e d } \\
\text { P r o d u c t i o n } \\
\text { Company }\end{array}$ & -9186420 & -2825271 & $\begin{array}{l}-11459 \\
43\end{array}$ & $\begin{array}{l}-39174 \\
99\end{array}$ & -1797597 & 0 & $\begin{array}{l}-756076 \\
6\end{array}$ \\
\hline 5 & $\begin{array}{l}\text { Iraqi Company } \\
\text { for the } \\
\text { Production and } \\
\text { Marketing of } \\
\text { Meat and Field } \\
\text { Crops }\end{array}$ & -6212331 & -1.311591 & $\begin{array}{l}-58896 \\
73\end{array}$ & $\begin{array}{l}-55729 \\
59\end{array}$ & -2.145211 & $\begin{array}{l}-77814 \\
22\end{array}$ & $\begin{array}{l}-1.00041 \\
1\end{array}$ \\
\hline 6 & $\begin{array}{l}\text { Iraqi Company } \\
\text { for the } \\
\text { Production and } \\
\text { Marketing of } \\
\text { Agricultural } \\
\text { Products }\end{array}$ & -1025691 & -1953162 & $\begin{array}{l}-76600 \\
67\end{array}$ & $\begin{array}{l}-39354 \\
77\end{array}$ & -2648307 & $\begin{array}{l}555005 \\
0\end{array}$ & 923717- \\
\hline
\end{tabular}

From the above financial analysis of the results of the EVA in table 9, it is revealed that there is a significant difference between the number of negative and positive values achieved over the period of six years. A total view of 5 positive values is recorded compared to 7 total views of negative values from the selected sample of total 42 views. There is average of 6 views for each company and one average for the six companies within six years.

From the results of the companies mentioned in the table 9 above, it is shown that there was a company that continuously achieved positive EVA of $16 \%$ out of the total selected six companies with a very small percentage that was represented by the Middle East Fish Production and Marketing Company. This revealed the existence of low rates of invested capital cost and an increase in the net profit achieved after the tax deduction which in turn is an indication that this company is effectively working. In other word, during the period of six years of study, there were three companies that could not achieve any economic value added as all of their results were negative or missing values. These are the companies under the Modern Company for Animal and Agricultural Production, the Iraqi Seed Production Company and the Private Company for Animal Production. This indicates that the profits mentioned in the financial statements of those companies are more accounting in nature rather than being real economic profits.

Submit Date: 10.01. 2018, Acceptance Date: 23.02.2018, DOI NO: 10.7456/1080MSE/120 
The profits are so minimal that they are not enough to cover the invested capitals. In the case of the Iraqi Company for the Production and the Marketing of Agricultural Products, there are inconsistently mixed results i.e. economic value added is achieved in one year and not in the other year. This shows the reversed nature of the relationship between the amount of the economic value added and the weighted average cost of capital (WACC).

From the previous result, it is clear that the agricultural sector of Iraq has become one of the worst economic sectors. This is as a result of neglecting the concept and application of EVA by the agricultural sector companies by focusing only on the accounting profits. Table 10 below shows the results from calculating the EVA from the highest and lowest economic value added along with the relevant mean for the selected six companies during the year of the study.

Table (10)

Highest, lowest and mean values of EVA

\begin{tabular}{|c|c|c|c|c|}
\hline Ref. & Company & Highest Value & Lowest Value & Mean Value \\
\hline 1 & $\begin{array}{l}\text { The Modern Company for } \\
\text { Animal and Agricultural } \\
\text { Production }\end{array}$ & -1.013631 & -5466779 & -5212921 \\
\hline 2 & $\begin{array}{l}\text { Private Company for Animal } \\
\text { Production }\end{array}$ & -1752993 & 0 & -1241344 \\
\hline 3 & $\begin{array}{l}\text { Middle East Fish Production \& } \\
\text { Marketing Company }\end{array}$ & 5089414 & -8226525 & 8272305 \\
\hline 4 & Iraqi Seed Production Company & -1145943 & 0 & -7560766 \\
\hline 5 & $\begin{array}{l}\text { Iraqi Company for the } \\
\text { Production and Marketing of } \\
\text { Meat and Field Crops }\end{array}$ & -1.311591 & -7781422 & -1.000411 \\
\hline 6 & $\begin{array}{l}\text { Iraqi Company for the } \\
\text { Production and Marketing of } \\
\text { Agricultural Products }\end{array}$ & 5550050 & -7660067 & 923717- \\
\hline
\end{tabular}

Submit Date: 10.01. 2018, Acceptance Date: 23.02.2018, DOI NO: 10.7456/1080MSE/120 


\section{CONCLUSIONS}

The following can be concluded from the study:

The result for correlation is positive between rise in the stock prices and economic value added.

Reliance on the economic profit and the commercial profit from the optimal use of resources leads to profits exceeding the invested capitalspent by the investor.

The application of EVA directly benefits all participating companies registered in the Iraqi Stock Exchange.

The EVA is a financial benchmark, not accounting benchmark.

A positive benchmark indicates that the return is greater than the costs. Hence, the company is creating value and consequently increasing the value of its shares while benefiting shareholder sand vice versa. There is a reduction in the company's stock values which negatively impacts shareholders whenever the result is negative.

One of the challenges facing the companies operating in the agriculture field is the instability in security situations and economics in a country. This is applicable to other factors present in the market with imported goods which increase the degree of uncertainty and risks.

The psychological and behavioral factors of investors and their pursuit of a higher turnover affect the capital invested.

Reliance on the accounting dimensions more while reducing the reliance on marketing dimension when attending to the items of the accounting lists. In terms of depicting the reality of the economy of the companies contributing to the agricultural companies listed in the Iraqi Stock Exchange, this has led to an adverse effect.

There is reduction in the degree of uncertainty and consequently result in optimal allocation of resources due to transparency and disclosure necessary for the implementation of this benchmark along with the traditional disclosure method; thus, finally achieving an economic development.

Negligence of this benchmark by the Iraqi Stock Exchange so far has restricted the stocks the ability to reflect the reality of the economy and the ability to be affected by the economy.

Five companies out of the six agricultural shareholding companies cannot achieve economic added value. Three out of the six companies have negative results while theprofits were only accounting in nature but not economic. Apparently, the negligence of the concept of economic value added (EVA) by the company and settling for accounting profits only in order to evaluate their status without creating any value for their stock has negatively affected possible desire to acquire those shares by the investors. This can be noticed in the very low rate of agricultural companies trading in the financial market.

\section{RECOMMENDATION}

Organizations should resort to modern economic indicators such as monetary value added and economic value added to complementary the traditional financial indicators as this will boost the opportunity to choose successful investments.

Submit Date: 10.01. 2018, Acceptance Date: 23.02.2018, DOI NO: 10.7456/1080MSE/120 
This benchmark/standard determines the necessity of using the EVA as benchmark by the financial intermediaries and Iraqi Stock Exchange in order to persuade their customers to trade shares that belong to companies to evaluate their performance while having positive EVA. Incentive should be create for managers to maintain a balance between long-term/strategic and short-term/operational management. Institution of management/board focusing on investment can create value for the investors in order to encourage them to invest in this field. The employees should be well-trained in order to apply the benchmark and link its application to the system of rewards and incentives. A positive change can be achieved from their behavior so as to be more integrated in the continuation and success of the work management which requires a more accurate and better system of information and data which is sometimes disclosed by the same companies to their shareholders, investors and employees. Application of EVA as benchmark in the competitive market is necessary to contribute to agricultural companies. Therefore, the significance of this benchmark (EVA) increases in the case of Iraq which belongs to the World Trade Organization. As EVA is among one of the modern benchmarks rarely applied in Iraq, it is important to spread the significance and concept of using the EVA through showcasing of its benefits especially those useful in rationalizing investors' decision.

\section{REFERENCES}

Al-Aqidi, M.A.M. The Reality of Agricultural Investment in the Republic of Iraq and its Future Influence, 2012.

Ali, M.A.A. Studying the Distribution of Economic Value Added as a Tool Complementary to Those Used for the Evaluation of Industrial Firms' Performance And Suggested Adjustments to Calculate It, Faculty of Administration and Economics, University of Aleppo,- Syria, 2015.

Al-Shibli, A.H.T. Using the Economic Value Added Approach Evaluate the Financial and Opertaional Performance in Economic Unites, Economics Magazine, University of Basrah, Iraq, 2009. № 23.

Awan, A. G., Siddique, K., \& Sarwar, G. The effect of Economic Value Added on stock return: Evidence from selected companies of Karachi stock exchange. Research Journal of Finance and Accounting, 2014. № 5(23). PP. 140-152.

Central Bank of Iraq Statistical, Statistics and Research Department, for the years of research. Cervantes-Godoy, D., \& Dewbre, J. Economic importance of agriculture for poverty reduction, 2010.

Flayyih, H.H. Evaluate the financial performance of the economic entities Using the economic value added An Empirical Study in State Company. Journal of Accounting and Financial Sciences, 2015.

Flayyih, H.H. Enhance financial reporting of companies to use economic value added Analytical study from the viewpoint of academics, practice. Baghdad College of Economic Sciences, 2015. № 43. PP. 379-408.

Hamza, N.A. Using for Economic Value Added Approach to Evaluate For Accounting Performance for Companies, Facultry of Commerce - Accounting and Auditing Department, Port Said University, 2014.

Harad, Z.B. The Role of Economic Value Added Benchmark in Evaluating Financial Performance of the Private Sector in Algeria, 2014.

ISX report, Annual and Semiannual Reports Issued by the Iraqi Stock Market for the years of research.

Koller, T., Goedhart, M., \& Wessels, D. Valuation: measuring and managing the value of companies (Vol. 499). john Wiley and sons, 2010.

Maditinos, D., Šević, Ž., \& Theriou, N. Economic Value Added (EVA). Is it Really the Best Performance Measure? A Review of the Theoretical and Empirical Literature. The Case of Athens Stock Exchange (ASE). Review of Economic Sciences, 2007.

Mashhadani, B.N. and Talab, H.R. The Role of Management Accountant In Implementing Corporate Governance Mechanisms. Journal of Economic and Administrative Sciences, 2013. № 49(71). PP. 454-473.

McNellis, P. E. Foreign investment in developing country agriculture-The emerging role of private sector finance. FAO Commodity and Trade Policy Research Working, 2009. P. 28

Mohammed, Y.N. The Integration of the Concepts of Accounting Income and Economic Value Added and its Role in Guiding Investors' decisions, College of Administration and Economics, Baghdad University, 2013

Submit Date: 10.01. 2018, Acceptance Date: 23.02.2018, DOI NO: 10.7456/1080MSE/120 
Ray, S. Efficacy of economic value added concept in business performance measurement. Advances in information technology and management, 2012. № 2(2), PP. 260-267.

Said. B \& Samir, M. Evaluation of Economic Establishment - Entry to the Economic Value Added, College of Economics and Management, Larbi Ben M'hidi El Bouaghi University, Algeria, 2014.

Saifi, H and Amara, N. Measuring Financial Performance Through the Use of Economic Value Added (EVA), Current Study - Université KasdiMerbah, Ouargla, Algerie, 2015.

Shleifer, A. Inefficient markets: An introduction to behavioural finance. OUP Oxford, 2000.

Stern, J. M., Shiely, J. S., \& Ross, I. The EVA challenge: implementing value-added change in an organization. John Wiley \& Sons, 2001.

Stern, J. M., Stewart, G. B., \& Chew, D. H. The EVA® financial management system. Journal of applied corporate finance, 1995. № 8(2). PP. 32-46.

Stiglitz, J. E. The role of the state in financial markets. The World Bank Economic Review, 1993. № 7(suppl_1).PP.19-52.

Talab, $\bar{H}$. R., Manaf, K. B. A., \& Malak, S. S. D. A. Ownership Structure, External Audit and Firm Performance in Iraq. Social Science and Humanities Journal, 2018. PP. 343-353.

Talab, H.R. A Suggested Model for The Role of Management Accounting Implementing Corporate Governance Mechanisms. Master Thesis. University of Baghdad, 2009.

Talab, H.R., Abdul Manaf, K.B., and Abdul Malak, S.S.D. Internal Audit Function, Ownership Structure and Firm Performance in Iraq. The 5th International Accounting and Business Conference. Malaysia, 2017.

Talab, H.R., Abdul Manaf, K.B., and Abdul Malak, S.S.D. Corporate Governance Mechanisms and Firm Performance in Iraq: A Conceptual Framework. Account and Financial Management Journal, 2017. № 2(11). PP. 1132- 1146.

Zafiris, N., \& Bayldon, R. Economic value added and market value added: A simple version and application. Journal of Applied Accounting Research, 1999. № 5(2). PP. 84-105.

Submit Date: 10.01. 2018, Acceptance Date: 23.02.2018, DOI NO: 10.7456/1080MSE/120

Research Article - This article was checked by Turnitin

Copyright (C) The Turkish Online Journal of Design, Art and Communication 